\title{
BUILDING SOCIAL CAPITAL THROUGH LEADER APPROACH 2007-2013: CASE OF LATVIA AND POLAND
}

Agnieszka WOJEWÓDZKA-WIEWIÓRSKA, Department of European Policy and Marketing, Warsaw University of Life Sciences, Nowoursynowska 166, 02-787 Warszawa, Poland, agnieszka_wojewodzka@sggw.pl(corresponding author)

Agnese KRIEVIN̦A, Division of Agricultural Development and Economic Relations, Institute of Agricultural Resources and Economics, Struktoru 14, Riga, LV-1039, Latvia, agnese.krievina@arei.lv

Ligita MELECE, Division of Quality and Environmental Protection, Institute of Agricultural Resources and Economics, Struktoru 14, Riga, LV-1039, Latvia, ligita.melece@ arei.lv

Building and developing social capital is regarded as a major factor underpinning the development of rural areas, while the LEADER approach to rural development has been found to have a great potential for creation and use of social capital. Therefore, the aim of the study is to explore the LEADER approach in building social capital in rural areas of Latvia and Poland, based on the thematic analysis of the implemented projects during 2007-2013. To achieve the objective, the study explores the introduction of the approach in Latvia and Poland, as well as presents project case studies for social capital formation in Latvia and Poland, by using appropriate materials and research methods. Projects carried out under the LEADER 2007-2013 in Latvia and Poland affect rural communities regarding social capital on different levels at the same time: build trust, create bonds around common values and raise citizens' involvement in joint initiatives. There are examples of projects that contribute to the building of structural social capital, relational social capital and cognitive social capital in Latvia and Poland. Overall, the thematic analysis of the realized projects in Latvia and Poland reveals that in relation to the social capital they have improved the possibilities for gathering and socialization, for participation in interest groups and associations. Never before in rural areas of Latvia and Poland there has been such a form of cooperation of different local actors, applying the bottom-up approach. Studies show that this approach works well in practice and brings the intended effects to rural development.

Keywords: RDP 2007-2013, LEADER approach, rural areas, social capital

\section{INTRODUCTION}

The idea of social capital is of interest to the representatives of the various scientific disciplines. Social capital describes the relationships among people (i.e. social ties, norms of mutuality and mutual trust); and it is based on a willingness to cooperate. Social capital can be defined as a set of informal values and ethical norms that are shared by the members of a certain group of people, which enables them to effectively cooperate towards achieving their intended goals. Members of a particular social group, who believe that the remaining members will act honestly and reliably towards them, place their trust in them, which improves the effectiveness of the functioning of the group or institution (Fukuyama, 2003). Social capital is based on the features of social life and it comes into being when the particular actions and activities are approved by most members of the group. Social capital encompasses the ties of trust, loyalty and solidarity, which is reflected in self-organization and self-government (Fukuyama, 1997).

Building and developing social capital is regarded as a major factor underpinning the development of rural areas (Kłodziński, 2003; Antoci et al, 2009; Wojewódzka-Wiewiórska, 2011a, 2011b; Lopolito et al., 2015), hence, in practice it is very important to support the formation of social capital. There are differences in the level of social capital between communities or society of areas (regions, countries), due to the differences in the factors influencing the development of social capital (Wojewódzka-Wiewiórska, 2015).

Starting from the programming period 2007-2013, LEADER has been mainstreamed as an integral part of all national rural development programmes (RDP), giving it the opportunity to be applied on a far wider scale and across a much broader range of rural development activities (EC, 2006).

LEADER (Liaison entre actions de développement rural (in French) - Links between actions of rural development) is a special local development approach for rural areas envisaged to encourage territories to explore new ways to be competitive, to make the best use of their resources and to overcome their challenges. The approach is based on bottom-up rural development actions, which include local businesses, representatives from civil society and local authorities joining together in a public-private partnership known as a Local Action Group (LAG). The LEADER approach is implemented in a LAG's territory based on its Local Development strategy (LDS) (EC, 2006; EC, 2011).

Copyright (C) 2017 The Authors. Published by Aleksandras Stulginskis University. This is an open-access article distributed under the terms of the Creative Commons Attribution License (CC-BY 4.0), which permits unrestricted use, distribution, and reproduction in any medium, provided the original author and source are credited. 
Allowing rural actors to design and implement their own local development strategies is considered important for a successful rural policy; and the LEADER approach is an evident example of a rural policy measure following these principles (Fałkowski, 2013). Furthermore, the LEADER is considered to be a tool that addresses the issues of rural development through the creation and use of social capital as a public-owned key resource for sustainable development. It is also believed that the LEADER approach contributes greatly to the aggregation of groups with a high level of social capital (Nardone et al., 2010).

Considering the potential of the LEADER approach to contribute to the social capital, the aim of the study is to explore the LEADER approach in building social capital in rural areas of Latvia and Poland, based on the thematic analysis of the implemented LEADER 2007-2013 projects. To achieve the objective, the study explores the implementation of LEADER approach in Latvia and Poland, as well as presents LEADER 2007-2013 project case studies for social capital building in Latvia and Poland.

\section{RESEARCH METHODS}

The principal materials used for the theoretical study are different sources of literature, e.g., scholars' articles, research papers and the reports of Latvian, Polish and foreign researchers, and institutions, including the informative brochures and reports of the LAG's on the implemented LEADER projects. Important sources of information have been the programming documents of the Ministry of Agriculture in Latvia and the Ministry of Agriculture and Rural Development in Poland, the financial data on the public funding spend on the measures of the RDPs, as well as the evaluation reports on the implementation of the LEADER approach.

The appropriate qualitative and quantitative research methods have been used in the process of the study: monographic, content analysis and synthesis, information and data grouping, logical and abstract constructive etc.

\section{RESEARCH RESULTS}

\section{Implementation of leader approach}

In the programming period 2007-2013, the LEADER approach in Latvia was implemented by 40 LAGs covering $100 \%$ of the eligible territory in Latvia, while in Poland there were 336 LAGs operating in $93 \%$ of the eligible territory of Poland (see Table 1). The approach was carried out through four main measures in Latvia (though, two of them were merged at a later phase) and three priority measures in Poland. The implemented measures and the respective activities they incorporated from Axis 1 and Axis 3 of the RDPs (including some additional activities not provided under Axis 3), with he the aims they pursued are depicted in Figure 1.

Table 1. Indicators of the implementation of the LEADER 2007-2013 in Latvia and Poland

\begin{tabular}{|l|c|c|}
\hline \multicolumn{1}{|c|}{ Specification } & Latvia & Poland \\
\hline total money spent on LEADER in million EUR & 39.6 & 791.4 \\
\hline number of LAGs & 40 & 336 \\
\hline \% of the eligible territory covered & 100 & 93 \\
\hline average number of inhabitants per LAG (thousands) & 25.2 & 53.7 \\
\hline
\end{tabular}

Source: AREI, 2016; ARMA, 2017; MARD, 2017

In total, almost EUR 40 million of public funding were spend on the LEADER projects in Latvia, which is almost $3 \%$ of the total RPD 2007-2013 funding (AREI, 2016), while in Poland the spending under Axis 4 amounted almost EUR 800 million which constituted $4.5 \%$ of its RDP (MARD, 2017). Majority (more than $80 \%$ ) of public funding under Axis 4 went to the diversification of rural economy and improvement of the quality of live on local area of these countries (Measure 413), followed by the expenditures for the running and activities of LAGs (Measure 431) (see Figure 1).

Regarding the quality of life of rural inhabitants (Measure 413), the results of the LEADER 2007-2013 implementation in Latvia (Krievina, Leimane, 2014) show that there were many projects realized to create the possibilities for active leisure time and sports, to form activity centres and develop hobby activities and amateur performances (Measure 413), to the latter the LEADER support contributed by giving the possibility to obtain national costumes for children, youth and senior dance groups and choirs, as well as to acquire music instruments and equipment for different amateur music bands. These projects contributed to the development of human capital in the rural area, as well as by the facilitation of interest activities contributed to the development of social capital because rural inhabitants had more and/or more qualitative possibilities to engage in different interest groups.

There was also a large group of projects implemented under Measure 413 aiming at the improvement of rural infrastructure and recreational environment in Latvia. Among these projects, it was very popular to establish playgrounds for children, to create and improve the recreational and sports area, cultural houses, houses for gathering and stages, including obtaining lighting and sound equipment for cultural events. The contribution of these projects to the development of social capital in rural area is directly linked with supporting of people gathering and socialization. There were also projects, which intended to preserve the cultural heritage - museums, churches, monuments and memorial places, manor houses and their parks, also some traditional craft workshops. These projects in addition contributed to the cultural and national values, which is also a part of social capital. Community values were also promoted by projects where the rendition of social support and social services were improved, as well as health and rehabilitation services 
provided. In addition, a number of entrepreneurship projects were carried out in Latvia (Measure 411), which present a network of work relationships and related values and skills.

\section{RDP 2007-2013}

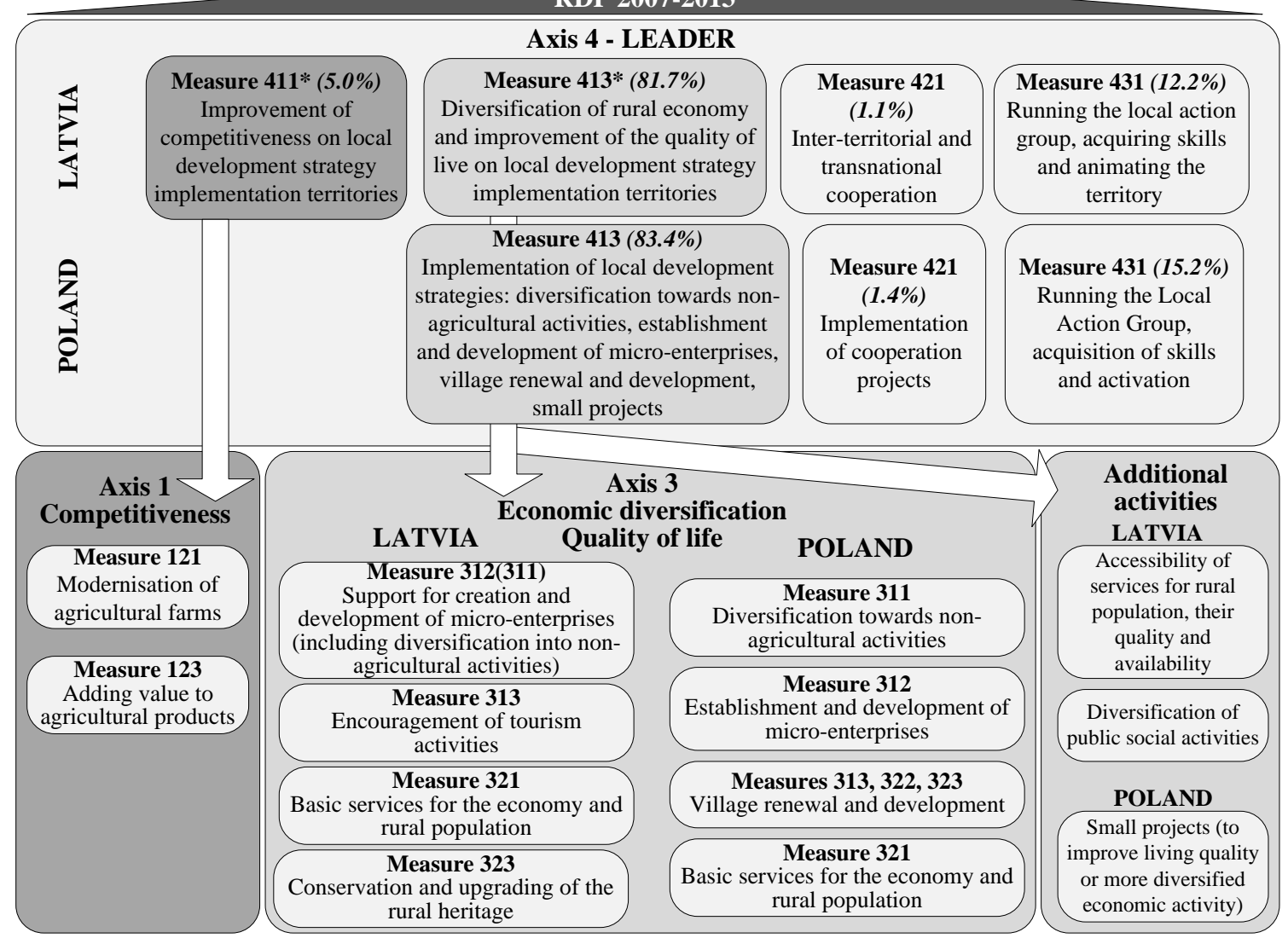

$\%$ - funding share in the LEADER for the country; *Measure 411 and 413 were merged in Latvia in 2012

Source: own construction, based on RDP, 2007; LAP, 2015; LAD, 2015; AREI, 2016; MARD, 2017

Figure 1. Implementation of the LEADER 2007-2013 measures in Latvia and Poland

Along with the support to LAGs activities (Measure 431), there were also several projects implemented under Measure 413 in order to strengthen the capacity of associations - their facilities were established, renovated or reconstructed and the necessary equipment was obtained. Furthermore, when looking at the date of the registration of the association submitting LEADER projects, it can be concluded that the availability of the LEADER funding itself promoted the creation of associations in Latvia, because a lot of associations were registered in the period when the support was available. Also, in the programming period 2007-2013, the number of the LAG and their covered territory has increased compared to 2004-2006 (ZM, 2009).

Also in Poland, the range of projects implemented under the LEADER approach in practice was very wide as a result of the structure of the RDP itself. These projects directly or indirectly influenced the development of social capital in rural areas. The first group of projects under Measure 413 concerned job creation outside of agriculture, although the importance of Axis 4 in this regard was small compared to Measures 311 and 312 of Axis 3. This group of projects, as well as those associated with the creation and development of micro-enterprises, has shaped the quality of human capital. As a result of these projects, there was an increase in the level of entrepreneurship and activity of rural residents, and local leaders emerged. The second group of projects concerned the shaping of living conditions in rural areas. One can distinguish here investment activities, mainly concerning renovation and furnishing of countryside common rooms, construction and marking of small tourist and recreational infrastructure (bicycle paths, playgrounds, out-door gyms), development of public space, restoration of historic buildings. As a result of these projects, the infrastructure has been created, which enables the meetings of the inhabitants, what was many times indicated in the field research (Ledzion et al., 2016). Projects related to the promotion of rural resources were also important, including the promotion of local cultural creativity, cultural heritage, cultivating local traditions, rituals and customs, regional language or traditional occupations and crafts. Within these activities, various types of local events were organized, which were very popular with the residents.

Under Measure 431, research on the LDS supported area was conducted and information on LAG activities and training for people involved in LDS implementation was provided in Poland, including local leaders. In addition, promotional and information events were organized. Thanks to these actions the social capital of the LAG itself has been strengthened. In the long perspective, this measure contributes to building of social capital in rural areas, and consequently to stimulation of local community involvement in the area development and better harness of the potential of rural areas.

Measure 421 included the implementation of projects of interregional and international cooperation, but it was financially small measure both in Latvia and Poland. In Latvia, all implemented projects (35 projects) facilitate the 
international cooperation and networking, and the strengthening of human and social capital in these projects was in the sphere of entrepreneurship and marketing, crafts and arts, as well as some projects were for the youth, culture and nature. In total, 223 cooperation projects were completed in Poland, with interregional projects dominating (85\% of all projects implemented) (ARMA, 2017). It was possible to implement projects for joint LAGs ventures or to prepare a draft of such cooperation.

\section{Social capital bulding - project case studies}

Various types of social capital are presented in literature. According to Nahapiet and Ghoshal (1998), social capital has three dimensions - structural, cognitive and relational. Structural social capital is commonly associated with interaction, social ties, linkages, networks and structures (Nahapiet, Ghoshal, 1998; Claridge, 2013; A/L Muniady et al., 2015; Ortiz et al., 2016). Generally, it is a set of social structures allowing interaction among individuals; and the size of this capital in a community depends of the amount of the links between the actors (Nardone et al., 2010).

Relational social capital concerns the quality of relationships between individuals and its basic element is trust (Nardone et al., 2006; Claridge, 2013; Ortiz et al., 2016; Lang, Ramirez, 2017).

Cognitive social capital is used to refer to shared values, attitudes, beliefs, meanings and interpretation, which allow individuals belonging to a group to make communication possible, to work towards mutually beneficial collective action, to reach a shared vision and collective goals of their community (Nahapiet, Ghoshal, 1998; Nardone et al., 2010; Claridge, 2013; Ortiz et al., 2016; Lang, Ramirez, 2017). The cognitive dimension concerns the ability to reach a shared vision of problems, leading to a shared development strategy (Nardone et al., 2006).

The common feature of all dimensions of social capital is that they can generate specific socio-economic benefits (Antoci et al, 2009; Wojewódzka-Wiewiórska, 2011b; Lopolito et al., 2015).

Further case studies of the implemented LEADER 2007-2013 projects are given for each dimension of social capital.

\section{- Structural social capital}

The building of structural social capital directly can be observed in all Latvian LEADER projects promoting the activities of interest groups, as well as the activities of associations, including the creation and activities of the partnership of local actors - LAGs. The building of structural social capital also took place outside the targets of the specific projects as the process of the establishing of new association to prepare and submit LEADER projects for their local needs was observed. For the facilitation of interest groups, there was an interesting project "IDEA MusicHouse", implemented by the association "NEXT", within LAG's "Liepaja District Partnership" territory. The project allowed to establish a music studio with professional music equipment in the premises of the IDEA House (place for youth initiatives). This music studio provided the unprecedented opportunity to learn and work with professional music equipment, to record and produce music, to establish music groups and organize music and entertainment events. Also, the association noted that the project has strengthened its capacity (Liepājas rajona partnerība, 2012).

One of the examples of the projects directly aiming at the strengthening of the capacity of associations in Latvia is "Aluksne municipality community centre - for the activities and cooperation of the NGOs of the region", realized by the association "Support centre for the NGOs of Aluksne", within the LAG's "Aluksne Rural Partnership" territory. As the result of the project, premises of the community centre were reconstructed, as well as the office furniture, multimedia projector, computers and digital camera were purchased for the needs of the community centre - to support NGOs activities, organise seminars, trainings, meetings and other events (Alūksnes lauku partnerība, 2015).

One example of a project in Poland that was to create new bonds between the various rural areas actors is the project "Joint Integration of the Village" implemented by the Voluntary Fire Brigade in Kościelisko in partnership with the Independent Women's Association on the premises of the LAG Gorna Prosta. Within the framework of the project, the common room was renovated and modernized, which provides a place for meetings and integration of the inhabitants, where events can be organized (Przegląd projektów.., 2015). It should be emphasized that the beneficiary is a volunteer fire brigade, which in the realities of the Polish countryside is a place that gathers local leaders in which the inhabitants have confidence. The project has strengthened this organization in the context of building social capital.

An example of a project that fosters co-operation of existing structures in the countryside is a project of cooperation "Cooking the Region's Attraction", implemented in partnership of two LAGs - LAG Ziemia Zamojska/Zamość Land and LGD Nasze Roztocze/Our Roztocze. Workshops for women that consisted of theoretical and practical part were organized. Participants divided into several subgroups were supposed to prepare two traditional dishes for each region (LGD Ziemia Zamojska, 2017). Such an initiative may be the basis for further co-operation of participants, e.g., organization of workshops as a cyclical event or publication of a culinary book.

\section{Relational social capital}

Considering the main LEADER 2007-2013 project groups, almost all projects for infrastructure and recreational environment in Latvia can be related to the relational social capital, because the common use of public places and publicly available inventory and equipment is not possible without mutual trust. The same applies also to the projects for interest groups and activities, as well as other LEADER projects, where shared inventory and equipment were obtained and shared facilities improved or established. As it was quite popular to create playgrounds through the projects, one of the examples for relational social capital building in Latvia is a project named "Creation of children playground in Blome parish", implemented by the association "GaisMa tuneli/Light in the tunnel", within the LAG's "Abula Rural Partnership" territory. Within a project, a playground that met today's requirements was established, intended for the playing, exercising and spending leisure time outdoors, suitable for children aged from 1.5 to 12 years, thus, facilitating to their physical, mental and social development (Abulas lauku partnerība, 2013). 
Building relational structural capital was also done through an interesting project named "Innovative equipment for local residents to process garden production", carried out by the association "Kraslava district farmer's association", within LAG's "Kraslava District Partnership" territory in Latvia. As a result of the project, 6 mobile fruit and vegetable dryers, a portable cold pressing oil press and a movable juice extraction kit were obtained, allowing the members of the organization and interested parties to process own garden production for domestic consumption, thus contributing to the rational use of agricultural resources and to the promotion of healthy food (Krāslavas rajona partnerība, 2012).

An example of activities aimed at shaping relations between rural residents in Poland is the project: "Educational workshops for creative women" implemented by the Commune Culture Center in Kluszkowce in the area of activities of the LAG Gorce Pieniny Association. Within the project, workshops were carried out, teaching how to make ornaments from felt (pendants, bracelets, brooches) and how traditionally adorn the highlander headkerchief (Stowarzyszenie Gorce Pieniny, 2017). Participants were women who run agri-tourism farms or other service activities. The theme of the project is also related to the preservation of the region's cultural heritage. As a result, the project builds trust among participants who have had the opportunity to meet other entrepreneurs in the area.

An interesting project "Park Development in Jedwabne" was carried out by the Jedwabno commune on the grounds of the LGD Brama Mazurskiej Krainy/Gateway of the Mazurian Land in Poland. As part of the project, paths and alleys have been built, connecting the various parts of park. In addition, the facility is equipped with park benches, waste bins, bird feeders, information boards and lighting. There was also a place for a bonfire (Przykłady projektów..., 2014). As a result, a meeting place for inhabitants has emerged, resulting in new relationships with people outside of family and neighbours and building trust.

\section{Cognitive social capital}

From the point of view of universal community values, the building of cognitive social capital in Latvia can be observed in the LEADER projects dealing with the conservation of the cultural heritage, as well as with social support and services, the latter of which covers the support to all vulnerable groups of the society - people with low incomes, people with disabilities, lonely retired people, young and/or single mums, people in crisis, youngsters with problems, abandoned children etc. In addition to the care and help for those in need, throughout the implemented projects, there can be recognized also such community values as children and youth; middle generation and seniors; education and human development; clean and safe environment; health and recreation; economic activity and competitiveness; nature and environmental protection etc. The authors believe that the building of cognitive dimension of social capital in these projects is expressed through increased sharing of a value, which leads to an increased collectively beneficial action in pursuing and strengthening the specific value. Also, preparing of LDSs with a common vision and evaluating of the submitted projects according to the relevant development strategy, as well as deciding on the project proposals within an inner-group of an applicant represent the strengthening of cognitive social capital.

A lot of projects, where the purchase of national costumes was envisaged in Latvia, not only improved the possibilities to engage in interest groups, but also contributed to the conservation of the cultural heritage. For example, there was a project named "Purchase of the national costumes for folk group "Egle", implemented by the association "Visi kopa/All together", within LAG's "Balvi District Partnership" territory. The project was implemented in order to preserve, to popularise and to pass on the non-material cultural heritage of Latgale. Within the project, 19 archaeological national costumes were obtained, improving also the possibility to renew the repertoire, to find new partners for cooperation and organise workshops (Balvu rajona partnerība, 2012).

One of the social projects in Latvia, was a project named "We are nearby". The aim of the project was to improve the quality of life for retired people and people with disabilities in Rubene parish; and it was carried out by the association "Udenszimes/Watersigns", within LAG's "Rural Partnership Selija" territory. As the result of the project, the necessary equipment for providing social services (a chainsaw, a brush cutter, a trimmer, a lawn mower etc.) were purchased, allowing to provide services for about 40 retired people of Rubene parish (Lauku partnerība Sēlija, 2012).

The project that referred to cognitive social capital in Poland was a project realized by the LAG Razem na wyżyny/Together on upland in collaboration with 3 other LAGs. The project "Ecology - who cares about the fate of civilization?", encompassed 27 communes and aimed to raise the environmental awareness of children and adults. Within the framework of the project a theatre production "From ecology let the world be famous", which was shown in 129 kindergartens for 5 thousand children, moreover a plastic contest was organized. Adults have been included in the action "Crush the garbage". There has been purchased and distributed over 2 thousand crushers for plastic cans and bottles. The summation of the project was to organize the conference (Stowarzyszenie razem na wyżyny, 2017). The wide territorial scope of the project has enabled many people to engage in joint efforts to achieve the goal of protecting the environment.

Another interesting example of building relationships among different groups of inhabitants in Poland is the project "Entrepreneurship youth cultivates traditions" implemented by Ziębickie Association JANINE and LAG Qwsi/“To the village". Within the project, 5 thematic workshops were organized for young people, who referred to traditional Polish professions. Workshops were conducted by people over the age of 50, (Qwsi, 2017) which contributed to intergenerational and cultural exchanges.

\section{CONCLUSIONS}

1. The projects implemented under the LEADER 2007-2013 approach in Latvia and Poland affect rural communities regarding social capital on different levels at the same time: build trust, create bonds around common values and raise citizens' involvement in joint initiatives. There are examples of projects that contribute to the building of structural 
social capital, relational social capital and cognitive social capital in Latvia and Poland. Projects analysed and their implementation show that the impact of the initiatives taken to increase the level of social capital depend on the characteristics of the inhabitants and the specific nature of the area in which they are carried out.

2. Overall, the thematic analysis of the implemented LEADER 2007-2013 projects in Latvia and Poland reveals that in relation to the social capital they have improved the possibilities for residents' gathering and socialization, for participation in interest groups and associations. The evaluation of the level of the impact, as well as the efficiency of the projects, their innovativeness and sustainability are beyond of the scope of this study.

3. Significant factor for building social capital in the rural areas is the design of the LEADER approach and its rules, as representatives of various sectors are involved. Never before in rural areas of Latvia and Poland there has been such a form of cooperation and consideration of problems from different points of view, applying the bottom-up approach. Studies show that this approach works well in practice and brings the intended effects by involving different individuals and entities in rural development.

\section{ACKNOWLEDGMENTS}

The paper was partly supported by the Latvian National Research Program 5.2.1. SUSTINNO.

\section{REFERENCES}

1. Abulas lauku partnerība. 2013. Bērnu totaļu laukuma izveide Blomes pagastā. Available at: http://www.abulas.lv/lv/projekti/db2014/13-leader-projekti/blomes-pagasts/104-rotallaukums (Acceessed 25/07/2017). [In Latvian]

2. Agency for Restructuring and Modernisation of Agriculture data (ARMA). 2017. Ministry of Agriculture and Rural Development in Poland.

3. Alūksnes lauku partnerība. 2015. LEADER Eiropas Savienības finansētie projekti vietējai attīstībai. Alūksnes lauku partnerība. [In Latvian]

4. Antoci, A., Sabatini, F., Sodini, M. 2009. Fragility of Social Capital. University of Siena.

5. AREI. 2016. Lauku attīstības programmas 2007-2013 Ex-post novērtējums (Ex-post evaluation of RDP 2007-2013). Research report, AREI. [In Latvian]

6. Balvu rajona partnerība. 2012. Iegādāti tautu tērpi folkloras kopai „Egle”. Available at: http://www.balvi.partneribas.lv/index.php/2014-09-23-05-37-42/istenotie-projekti/vi-riciba/49-iegadati-tautu-terpi-folkloraskopai-egle (Accessed 25/07/2017). [In Latvian]

7. Claridge, T. 2013. Explanation of types of social capital. Available at: http://www.socialcapitalresearch.com/explanation-typessocial-capital/ (Accessed 17/07/2017).

8. European Commission (EC). 2006. The Leader approach: a basic guide. Available at: http://enrd.ec.europa.eu/enrdstatic/fms/pdf/2B953E0A-9045-2198-8B09-ED2F3D2CCED3.pdf (Accessed 28/07/2017).

9. European Commission (EC). 2011. The European Agricultural Fund for Rural Development: Examples of Leader projects. Available at: http://enrd.ec.europa.eu/enrd-static/fms/pdf/C2098A13-A094-502B-81FA-4C9E46AB658D.pdf (Accessed 28/07/2017).

10.Fałkowski, J. 2013. Political accountability and governance in rural areas: Some evidence from the Pilot Programme LEADER+ in Poland. Journal of Rural Studies, Vol. 32, pp.70-79. https://doi.org/10.1016/j.jrurstud.2013.04.008

11.Fukuyama, F. 1997. Trust. Social capital and the way to prosperity, PWN, Warsaw-Wroclaw.

12.Fukuyama, F. 2003. Social capital, [in:] Harrisom L.E., Huntington S.P. (ed.), Culture is important, Zysk i S-ka, Poznań.

13.Kłodziński, M. 2003. Kapitał społeczny jako podstawowy czynnik różnicujący stopień rozwoju gospodarczo-społecznego gmin wiejskich (Social Capital as the Main Factor Differentiating the Degree of Economic and Social Development of Rural Communities). In M. Adamowicz (Eds.), The Local Development Strategies. Institutional Aspects, Vol. I (pp. 161-169). Warszawa. Wydawnictwo SGGW. [In Polish]

14.Krāslavas rajona partnerība. 2012. Īstenotie LEADER projekti Krāslavas rajona partnerības teritorijā 2009-2011.gadā, Krāslavas rajona partnerība. [In Latvian]

15.Krieviņa, A., Leimane, I. 2014. Lauku attīstības programma 2007-2013. LEADER pasākumu un 3.2.1. pasākuma rezultāti (iespēju robežās ietverot arī 2004-2006.g. periodu) un to ietekme uz uzñēmējdarbības attīstî̉bu lauku teritorijās (Results and impact of RDP 2007-2014 LEADER measureas and measure 3.2.1. on the development of entrepreneurship in rural area). Research report, LVAEI. [In Latvian]

16.Lang, T., Ramírez, R. 2017. Building new social capital with scenario planning. Technological Forecasting \& Social Change, Vol. 124, pp. 51-65 https://doi.org/10.1016/j.techfore.2017.06.011

17.Latvijas lauku attīstības programma 2007-2013 gadam (LAP). $2015 . \quad$ Available at: https://www.zm.gov.lv/public/files/CMS_Static_Page_Doc/00/00/00/69/57/LAP_2007-213_versija_15_clean.pdf (Accessed 18/07/2017).

18.Lauku atbalsta dienests (LAD). 2015. Informācija par apmaksātajiem ELFLA (2007-2013 plānošanas periods) projektiem. Available at: http://www.lad.gov.lv/files/elfla $2007 \quad 2013 \quad 31 \quad 12$ 2015.pdf (Accessed 19/07/2017).

19.Lauku partnerība Sēlija. 2012. "Lauku partnerība Sēlija” rok! İstenotie LEADER programmas projekti 2009-2011., Lauku partnerība Sēlija. [In Latvian]

20.Ledzion, B., Grabowska, I., Kupiec, T., Płoszaj, A., Widła-Domaradzki, Ł., Wojewódzka-Wiewiórska, A., Rauzer A., Wójtowicz, D. 2016. Ocena wpływu PROW 2007-2013 na jakość życia na obszarach wiejskich z uwzględnieniem podejścia LEADER (Evaluation of the RDP 2007-2013 impact on quality of life in rural areas taking into account the LEADER approach), Evaluation report, Warsaw: EGO. [In Polish] 
21.LGD Ziemia Zamojska, Warsztaty kulinarne w gminie Skierbieszowie. Available at: http://www.lgdziemiazamojska.pl (Accessed 01/08/2017)

22.Liepājas rajona partnerība. 2012. LEADER iniciatīva dz̄ives kvalitātes uzlabošanai cilvēkiem laukos, Liepājas rajona partnerība. [In Latvian]

23. Lopolito, A., Sisto, R., Barbuto, A., Da Re R. 2015. What is the impact of LEADER on the local social resources? Rivista di Economia Agraria, Vol. LXX, No. 1, pp. 55-75. https://doi.org/10.13128/REA-16977.

24.Ministry of Agriculture and Rural Development in Poland (MARD). 2017, Collective current report on the implementation of the Rural Development Programme 2007-2013 as at 31 December 2015.

25.Muniady, R., Al Mamun A., Mohamad, M.R., Permarupan P. Y., Zainol, N.R.B. 2015. The Effect of Cognitive and Relational Social Capital on Structural Social Capital and Micro-Enterprise Performance. Sage Open, 5, pp. 1-9. https://doi.org/10.1177/2158244015611187

26.Nahapiet, J., Ghoshal, S. 1998. Social Capital, Intellectual Capital, and the Organizational Advantage. The Academy of Management Review, Vol. 23, pp. 242-266.

27.Nardone, G., Sisto, R., Lopolito, A. 2010. Social Capital in the LEADER Initiative: a methodological approach. Journal of Rural Studies, Vol. 26, pp. 63-72. https://doi.org/10.1016/j.jrurstud.2009.09.001

28.Ortiz, B., Donate, M. J., Guadamillas, F. 2016. Relational and cognitive social capital: their influence on strategies of external knowledge acquisition. Procedia Computer Science, Vol. 99, pp. 91-100. https://doi.org/10.1016/j.procs.2016.09.103

29.Przegląd projektów realizowanych ze środków Unii Europejskiej w ramach PROW 2007 - 2013, 2015. LGD Górna Prosna, Opole. [In Polish]

30.Przykłady projektów zrealizowanych na obszarze LGD „Brama Mazurskiej Krainy” ze środków PROGRAMU LEADER PROW 2007-2013, LGD Brama Mazurskiej Krainy, 2014. Nidzica. [In Polish]

31.Qwsi, Przedsiębiorcza młodzież kultywuje tradycje, małe projekty. Availabel at: http://www.projekty.qwsi.pl (Accessed 29/07/2017). [In Polish]

32.Rural Development Programme for 2007-2013 (RDP). 2007. Ministry of Agriculture and Rural Development in Poland. Warsaw.

33.Stowarzyszenie Gorce Pieniny, Edukacyjne warsztaty dla kreatywnych pań. Available at: http://www.leadergorce-pieniny.pl (Accessed 29/07/2017). [In Polish]

34.Stowarzyszenie Razem na wyżyny, Zrealizowane projekty. Available at: https://razemnawyzyny.pl/o-lgd/zrealizowane-projekty (Accessed 01/08/2017). [In Polish]

35.Wojewódzka-Wiewiórska, A. 2011a. Determinants of Rural Areas Development in the Theory. Development Prospects of Rural Areas Lagging Behind in the CEE Region, pp. 186-92, Godollo, Hungary, Szent Istvan University.

36.Wojewódzka-Wiewiórska, A. 2011b. Social Capital as an Endogenous Factor of Local Development. Roczniki Naukowe SERiA, Vol XIII, Iss. 6. Warsaw-Poznan- Wroclaw.

37.Wojewódzka-Wiewiórska, A. 2015. Structural Dimension of Social Capital in Poland. Urban Versus Rural Areas. Proceedings of the 7th International Scientific Conference: Rural Development, pp. 1-6, Kaunas, Lithuania, Aleksandras Stulginskis University.

38.Zemkopības Ministrija (ZM). 2009. LEADER pieeja: pieredze un iespējas. Available at: https://www.zm.gov.lv/public/files/CMS_Static_Page_Doc/00/00/00/22/62/LEADER_pieeja_2007_2013.pdf (Accessed 28/07/2017). 